\title{
ANALISIS KEPUASAN PASIEN TERHADAP PELAYANAN RAWAT JALAN DI RS AZRA TAHUN 2019
}

\author{
Zulaika $^{1^{*}}$, Suhermi ${ }^{2}$, Rinto Rivanto ${ }^{3}$ \\ ${ }^{1,2,3}$ Program Diploma DIII Manajemen Pelayanan Rumah Sakit \\ Prodi MPRS Universitas MH Thamrin, \\ "Email: zulaikafiona@gmail.com
}

\begin{abstract}
ABSTRAK
Kepuasan pasien merupakan tingkat kesesuaian antara ekspektasi pasien terhadap pelayanan yang ideal dan persepsi pasien terhadap pelayanan nyata yang mereka terima. Terdapat 5 dimensi kualitas pelayanan yaitu, tangible (berwujud), realibility (keandalan), responsiveness (daya tanggap), assurance (jaminan), dan emphaty (kesedian untuk peduli). Tujuan penelitian ini adalah menganalisis kepuasan pasien terhadap pelayanan rawat jalan di RS Azra tahun 2019. Metode penelitian ini deskriptif dengan metode IPA (Importance Performance Analisis). Berdasarkan umur responden, paling banyak berusia < dari 40 tahun yaitu 101 responden $(74,8 \%)$, berdasarkan jenis kelamin paling banyak berjenis kelamin perempuan yaitu 106 responden $(78,5 \%)$, berdasarkan pendidikan yang terbanyak merupakan pendidikan tinggi yaitu 76 responden $(57 \%)$, berdasarkan pekerjaan responen terbanyak tidak bekerja yaitu 73 responden $(56,3 \%)$ dan berdasarkan pembiayaan yang terbanyak menggunakan pembiayaan non BPJS yaitu 107 responden (79,3\%). Dari 5 Dimensi yang diteliti tangible (berwujud), realibility (keandalan), responsiveness (daya tanggap), assurance (jaminan), dan emphaty menunjukkan pelayanan Rumah Sakit Azra sudah sangat baik dengan nilai rata-rata kepuasana pasien $94 \%$, hal ini sudah sesuai dengan standar mutu pelayanan pasien $90 \%$.
\end{abstract}

Kata Kunci: kepuasan pasien, pelayanan, rawat jalan

\begin{abstract}
Patient satisfaction is the level of conformity between patients 'expectations of the ideal service and patients' perceptions of the real services they received. There were 5 dimensions of service quality, tangible, reliability, responsiveness, assurance, and empathy (willingness to care). This study aimed to analyze the Patient Satisfaction of Outpatient Services in Azra Hospital 2019. The research method used descriptive method with the IPA (Importance Performance Analysis) method. The results showed that the largest respondents aged <from 40 years, 101 respondents $(74,8 \%)$. the majority of respondents were female, 106 respondents (78,5\%). Most respondents have a higher education background, 76 respondents (56,3\%). Most respondents were unemployed, 73 respondents (54\%) and most respondents paid services without insurance / non-BPJS, 107 respondents (79,3\%). Based on the 5 dimensions studied, tangible, reliability, responsiveness, assurance and empathy, Azra Hospital showed
\end{abstract}


very good service with an average patient satisfaction rate of 94\%. this is in accordance with the quality standard of patient services which is $90 \%$

Keywords: patient satisfaction, services, outpatient

\section{PENDAHULUAN}

Kepuasan pasien merupakan tingkat kesesuaian antara ekspektasi pasien terhadap pelayanan yang ideal dan persepsi pasien terhadap pelayanan nyata yang mereka terima. Tjiptono (2007) menyatakan bahwa terdapat 5 dimensi kualitas pelayanan yaitu, tangible (berwujud), realibility (keandalan), responsiveness (daya tanggap), assurance (jaminan), dan emphaty (kesedian untuk peduli).

Supartiningsih (2017) dalam penelitiannya di RS Sarila Husada menyebutkan bahwa variable keandalan (reability) dan variable jaminan (assurance) berpengaruh positif pada kepuasan pasien. Hal ini menunjukkan bahwa jika kemampuan pelayanan dengan segera dan memuaskan sesuai dengan harapan pasien maka pasien rawat jalan akan meningkat juga. Sedangkan menurut Sinaga (2018), dalam penelitiannya di RS Misi Lebak mengungkapkan bahwa pasien yang menerima pelayanan Empati memiliki kepuasan lebih 5,5 kali dibandingkan dengan pasien yang tidak mendapatkan pelayanan empati.

RS Azra Bogor merupakan Rumah Sakit Umum Swasta type C yang memiliki lebih dari 100 tempat tidur. Rumah Sakit AZRA pada tahun 2017 meraih Akreditasi KARS versi 2012 dengan predikat PARIPURNA. Dengan nilai tersebut, RS Azra harus selalu mempertahankan kualitas pelayanan kepada pasien terutama pasien rawat jalan. Kepuasan pasien merupakan modal utama meningkatkan jumlah kunjungan pasien ke rumah sakit. Dengan demikian penulis tertarik untuk menganalisis kepuasan pasien di poli rawat jalan RS Azra tahun 2019.

\section{METODOLOGI PENELITIAN}

\section{Desain Penelitian}

Penelitian ini menggunakan pendekatan cross sectional yaitu variabel-variabel faktor resiko dan variabel-variabel efek di ukur secara bersamaan pada waktu yang sama (Soekidjo Notoatmojo, 2002). Tujuannya adalah untuk melihat hubungan dimensi kepuasan pasien dengan pelayanan poli rawat jalan. Lokasi dan Waktu Penelitian ini dilakukan pada bulan Oktober-November 2019 di RS Azra Bogor

\section{Populasi dan Sample Penelitian}

Populasi dalam penelitian ini adalah seluruh pasien rawat jalan yang ada di RS Azra Bogor. Sampel penelitian ini 135 orang, cara pengambilan sampel purposif sampling, dan yang bersedia menjadi responden 135 orang.

\section{Analisis data}

Analisis data yang dilakukan adalah melalui statistik deskriptif dan analisis dengan Importance Performance Analysis. 


\section{HASIL DAN PEMBAHASAN}

\section{Karakteristik Responden}

Dari hasil penelitian diperoleh gambaran karakteristik responden yang berkunjung ke RS Azra Bogor yang tertera pada table 4.1. Berdasarkan umur responden paling banyak berusia $<$ dari 40 tahun yaitu 101 responden $(74,8 \%)$, berdasarkan jenis kelamin paling banyak berjenis kelamin perempuan yaitu 106 responden $(78,5 \%)$, berdasarkan pendidikan yang terbanyak merupakan pendidikan tinggi yaitu 76 responden $(56,3 \%)$, berdasarkan pekerjaan responen terbanyak tidak bekerja yaitu 73 responden (54\%) dan berdasarkan pembiayaan yang terbanyak menggunakan pembiayaan non BPJS yaitu 107 responden $(79,3 \%)$.

Tabel 1. Distribusi Frekuensi Karakteristik Pasien Rawat Jalan di RS Azra Bogor

\begin{tabular}{cccc}
\hline No & Variabel & Jumlah & Persentase \\
\hline $\mathbf{1 .}$ & Umur & & \\
& $<40$ tahun & 101 & 74,8 \\
& $>=40$ tahun & 34 & 25,2 \\
\hline 2. & Jenis kelamin & & \\
& Laki-laki & 29 & 21,5 \\
& Perempuan & 106 & 78,5 \\
\hline 3. & Pendidikan & & \\
& Tinggi & 76 & 56,3 \\
& Sedang & 51 & 37,7 \\
& Rendah & 8 & 6 \\
\hline 4. & Pekerjaan & & \\
& Bekerja & 62 & 46 \\
$\quad$ Tidak bekerja & 73 & 54 \\
\hline 5. & Pembiayaan & & \\
& BPJS & 28 & 20,7 \\
& Non BPJS & 107 & 79,3 \\
\hline
\end{tabular}

\section{Analisis Tingkat Kepuasan Pasien terhadap Pelayanan Rawat Jalan di RS Azra Bogor}

Pernyataan kepuasan dan tidakpuasan pasien merupakan hasil dari perbedaan antara harapan dan kenyataan yang dirasakan. Pasien dinyatakan puas apabila pelayanan yang diberikan sama atau lebih dari yang diharapkan. Hasil kepuasan pasien diperoleh dengan membandingkan tingkat kesesuaian antara harapan dan kenyataan. Tabel 2 menunjukkan bahwa setiap dimensi yang dibandingkan dengan harapan dan kenyataan dengan hasil kesesuaian memuaskan dengan tingkat kesesuaian tertinggi 98,3 terdapat pada dimensi responsiveness dan tingkat kesesuaian terendah 91,5 terdapat pada dimensi Emphaty. Hasil ini menggunakan Importance Performance Analysis. Adapun analisis kepuasan dengan Kuadran berdasarkan Diagram Kartesius ditunjukan oleh Gambar 1.

\section{Kuadran A}

Kuadran A menunjukkan faktor-faktor yang penanganannya perlu diprioritaskan karena keberadaan faktor-faktor inilah yang sangat penting oleh pelanggan, namun pelaksanaannya masih mengecewakan dan belum memuaskan. Dalam diagram kartesius tidak terdapat penangangan yang perlu diperioritaskan karena sebagian besar pasien sudah puas dengan pelayanan yang diberikan 


\section{Kuadran B}

Kuadran B menunjukkan faktor-faktor yang perlu dipertahankan karena pada umumnya tingkat pelaksaannya dianggap sangat penting dan telah sesuai dengan harapan pasien sehingga dapat memuaskan pasien rawat jalan terdiri atas:

a. Item 1, Prosedur penerimaan pasien yang cepat dan tepat

b. Item 2, Pelayanan pemeriksaan diagnosis dan perawatan terhadap pasien yang cepat dan tepat

c. Item 4 , Prosedur pelayanan rawat jalan mudah

d. Item 15, Dokter Memberikan perhatian terhadap keluhan pasien dan keluarganya

e. Item 16, Petugas memberikan pelayanan kepada semua pasien tanpa memandang status sosial

f. Item 19, Kebersihan, kerapihan dan kenyamanan ruang rawat jalan

g. Item 21, Kelengkapan, kesiapan dan kebersihan alat-alat pemeriksaan yang digunakan

\section{Kuadran C}

Kuadran C menunjukkan faktor-faktor yang kurang penting pengaruhnya bagi pasien, pelaksanaannya biasa-biasa saja dan dianggap cukup memuaskan yaitu:

a. Item 5, Kemampuan dokter dan perawat rawat jalan untuk cepat tanggap menyelesaikan keluhan pasien

b. Item 6, Petugas memberikan informasi dengan jelas, mudah dimengerti oleh pasien

c. Item 7, Dokter didampingi oleh perawat dalam memeriksa pasien

d. Item 11, Petugas kesehatan memberikan pelayanan sesuai dengan kebutuhan layanan kesehatan

e. Item 20, Penataan ruang rawat jalan (luar dan dalam)

f. Item 22, Kebersihan dan kerapihan penampilan petugas

\section{Kuadran D}

Kuadran D menunjukkan faktor-faktor yang dianggap pasien kurang penting namun pelaksanaannya berlebihan dan dilakukan dengan baik sekali dalam pelayanan administrasi sehingga sangat memuaskan terdiri atas:

a. Item 3, Jadwal pelayanan rumah sakit tepat waktu

b. Item 9, Kewajaran biaya/tarif dalam pelayanan

c. Item 10, Pelayanan yang diberikan sesuai dengan standar pelayanan

d. Item 12, RS memiliki sarana untuk menyampaikan pengaduan dan keluhan

e. Item 13, Pengelohan keluhan dan pengaduan dilaksanakan dengan baik

Tabel 2. Kesesuaian Harapan dan Kenyataan

\begin{tabular}{|c|c|c|c|c|c|c|c|}
\hline \multirow[b]{2}{*}{ No. } & \multirow[b]{2}{*}{ Pernyataan Dimensi } & \multicolumn{2}{|c|}{ Kinerja } & \multicolumn{2}{|c|}{ Harapan } & \multirow[b]{2}{*}{$\begin{array}{l}\text { TK } \\
(\%)\end{array}$} & \multirow[b]{2}{*}{$\begin{array}{c}\text { Kriteria } \\
\text { Kesesuaian }\end{array}$} \\
\hline & & $\begin{array}{l}\text { Skor } \\
\text { total }\end{array}$ & $\begin{array}{c}\text { Rata-rata } \\
\text { jawaban } \\
\text { responden }\end{array}$ & Skor total & $\begin{array}{l}\text { Rata-rata } \\
\text { jawaban } \\
\text { responden }\end{array}$ & & \\
\hline \multicolumn{8}{|c|}{ Reability } \\
\hline 1. & $\begin{array}{l}\text { Prosedur penerimaan pasien } \\
\text { yang cepat dan tepat }\end{array}$ & 535 & 3.96 & 569 & 4.21 & 94.1 & M \\
\hline 2. & $\begin{array}{l}\text { Pelayanan pemeriksaan } \\
\text { diagnosis dan perawatan } \\
\text { terhadap pasien yang cepat dan } \\
\text { tepat }\end{array}$ & 540 & 4.00 & 576 & 4.27 & 93.7 & M \\
\hline 3. & Jadwal pelayanan rumah sakit & 516 & 3.82 & 554 & 4.10 & 93.2 & $\mathrm{M}$ \\
\hline
\end{tabular}




\begin{tabular}{|c|c|c|c|c|c|c|c|}
\hline & tepat waktu & & & & & & \\
\hline 4. & $\begin{array}{l}\text { Prosedur pelayanan rawat jalan } \\
\text { mudah }\end{array}$ & 530 & 3.93 & 568 & 4.21 & 93.3 & M \\
\hline & Rata-rata & & & & & 93.5 & M \\
\hline \multicolumn{8}{|c|}{ Responsivennes } \\
\hline 5. & $\begin{array}{l}\text { Kemampuan dokter dan } \\
\text { perawat rawat jalan untuk cepat } \\
\text { tanggap menyelesaikan keluhan } \\
\text { pasien }\end{array}$ & 537 & 3.98 & 560 & 4.15 & 95.9 & $\mathrm{M}$ \\
\hline 6. & $\begin{array}{l}\text { Petugas memberikan informasi } \\
\text { dengan jelas, mudah dimengerti } \\
\text { oleh pasien }\end{array}$ & 530 & 3.93 & 558 & 4.13 & 95.2 & M \\
\hline 7. & $\begin{array}{llr}\text { Dokter } & \text { didampingi oleh } \\
\text { perawat } & \text { dalam memeriksa } \\
\text { pasien } & & \end{array}$ & 542 & 4.01 & 551 & 4.08 & 98.3 & M \\
\hline 8. & $\begin{array}{lr}\text { Tindakan } & \text { cepat pada saat } \\
\text { pasien } & \text { membutuhkan } \\
\text { pelayanan } & \end{array}$ & 532 & 3.94 & 565 & 4.19 & 94.0 & $\mathrm{M}$ \\
\hline & Rata-rata & & & & & 95.5 & M \\
\hline \multicolumn{8}{|c|}{ Assurance } \\
\hline 9. & $\begin{array}{l}\text { Kewajaran biaya/tarif dalam } \\
\text { pelayanan }\end{array}$ & 500 & 3.70 & 539 & 3.99 & 92.7 & M \\
\hline 10. & $\begin{array}{lrr}\begin{array}{l}\text { Pelayanan } \\
\text { sesuai }\end{array} & \text { yang } & \text { diberikan } \\
\text { pelayanan } & \text { dengan } & \text { standar } \\
\end{array}$ & 519 & 3.84 & 551 & 4.08 & 94.1 & M \\
\hline 11. & $\begin{array}{l}\text { Petugas kesehatan memberikan } \\
\text { pelayanan sesuai dengan } \\
\text { kebutuhan layanan kesehatan }\end{array}$ & 527 & 3.90 & 555 & 4.11 & 94.9 & M \\
\hline 12. & $\begin{array}{l}\text { RS memiliki sarana untuk } \\
\text { menyampaikan pengaduan dan } \\
\text { keluhan }\end{array}$ & 522 & 3.87 & 553 & 4.10 & 94.4 & $\mathrm{M}$ \\
\hline 13. & $\begin{array}{lr}\begin{array}{l}\text { Pengelohan } \\
\text { pengaduan } \\
\text { dengan baik }\end{array} & \begin{array}{r}\text { keluhan dan } \\
\text { dilaksanakan }\end{array} \\
\end{array}$ & 506 & 3.75 & 552 & 4.09 & 91.7 & M \\
\hline & Rata-rata & & & & & 94.3 & M \\
\hline \multicolumn{8}{|c|}{ Emphaty } \\
\hline 14. & $\begin{array}{l}\text { Perawat Memberikan perhatian } \\
\text { kepada setiap pasien }\end{array}$ & 526 & 3.90 & 565 & 4.19 & 93.1 & M \\
\hline 15. & $\begin{array}{l}\text { Dokter Memberikan perhatian } \\
\text { terhadap keluhan pasien dan } \\
\text { keluarganya }\end{array}$ & 532 & 3.94 & 563 & 4.17 & 94.5 & M \\
\hline 16. & $\begin{array}{l}\text { Petugas memberikan pelayanan } \\
\text { kepada semua pasien tanpa } \\
\text { memandang status sosial }\end{array}$ & 523 & 3.87 & 571 & 4.23 & 91.5 & M \\
\hline 17. & $\begin{array}{l}\text { Terjalin komunikasi yang baik } \\
\text { antara petugas rawat jalan } \\
\text { dengan pasien }\end{array}$ & 520 & 3.85 & 565 & 4.19 & 91.9 & M \\
\hline & Rata-rata & & & & & 92.5 & M \\
\hline \multicolumn{8}{|c|}{ Tangibel } \\
\hline 18 & $\begin{array}{l}\text { Pelayanan petugas rawat jalan } \\
\text { ramah dan sopan }\end{array}$ & 526 & 3.90 & 560 & 4.19 & 94.0 & $\mathrm{M}$ \\
\hline 19. & $\begin{array}{l}\text { Kebersihan, kerapihan dan } \\
\text { kenyamanan ruang rawat jalan }\end{array}$ & 532 & 3.94 & 568 & 4.21 & 93.6 & M \\
\hline & $\begin{array}{l}\text { Penataan ruang rawat jalan } \\
\text { (luar dan dalam) }\end{array}$ & 526 & 3.90 & 557 & 4.13 & 93.4 & M \\
\hline
\end{tabular}




\begin{tabular}{|c|c|c|c|c|c|c|c|}
\hline 21. & $\begin{array}{l}\text { Kelengkapan, kesiapan dan } \\
\text { kebersihan alat-alat } \\
\text { pemeriksaan yang } \\
\text { digunakan }\end{array}$ & 537 & 3.98 & 569 & 4.21 & 94.5 & M \\
\hline \multirow[t]{2}{*}{22.} & $\begin{array}{l}\text { Kebersihan dan } \\
\text { penampilan petugas }\end{array}$ & 539 & 3.99 & 553 & 4.10 & 97.3 & M \\
\hline & Rata-rata & & & & & 94.5 & $\mathrm{M}$ \\
\hline \multicolumn{3}{|c|}{ Jumlah Keseluruhan } & . & & & 2070.2 & \\
\hline \multicolumn{3}{|c|}{ Rata-rata Kepuasan Pasien } & & & & 94.0 & $\mathbf{M}$ \\
\hline
\end{tabular}

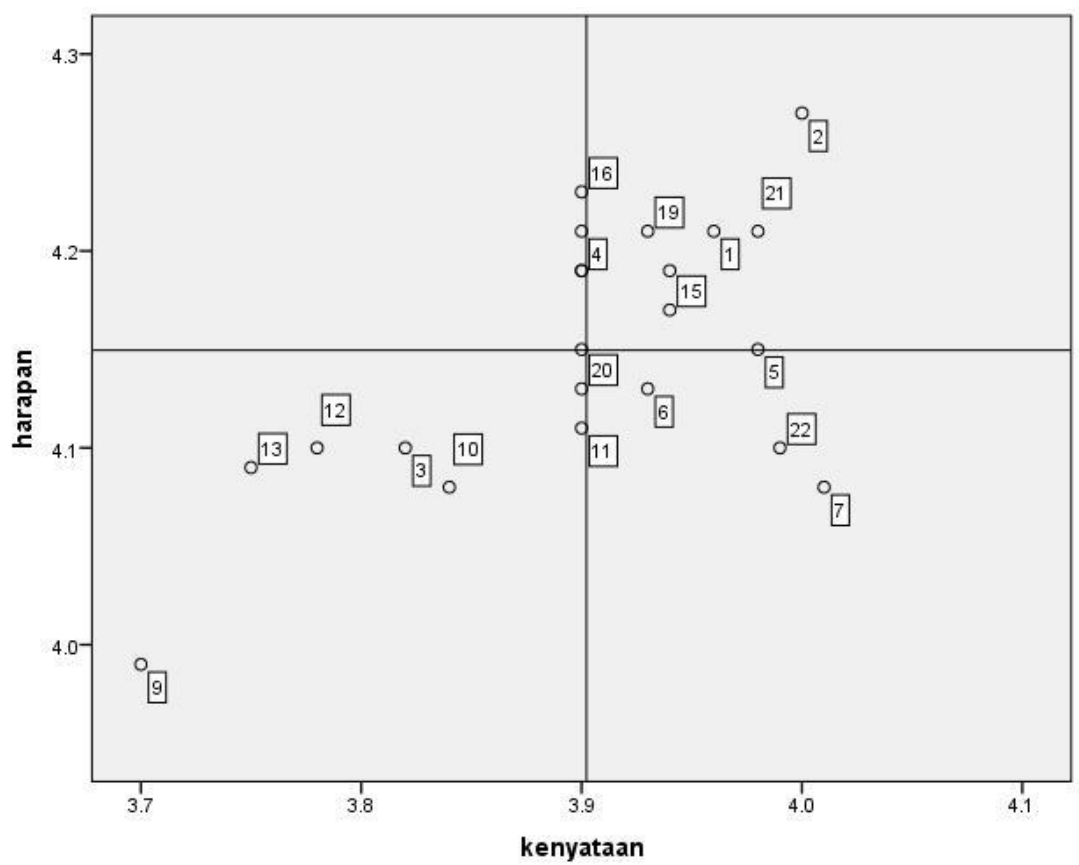

Gambar 1. Analisis kepuasan dengan Kuadran berdasarkan Diagram Kartesius

Penilaian pasien terhadap pelayanan rawat jalan RS Azra pada dimensi reliability, responsivennes, assurance, emphaty, dan tangible semua terdistribusi pada penilaian memuaskan. Berdasarkan hasil penelitian terhadap 135 responden diketahui bahwa sebagian besar jumlah responden sebanyak $74,8 \%$ adalah pada usia $18-40$ tahun atau usia produktif dan paling banyak adalah berjenis kelamin perempuan 106 orang $(78,5 \%)$. Dari tingkat pendidikan dapat diketahui bahwa jumlah responden yang memanfaatkan pelayanan rawat jalan paling banyak memiliki tingkat pendidikan akademi/perguruan tinggi sebanyak 76 orang (56,3\%). Mayoritas responden tidak bekerja yaitu ibu rumah tangga sebanyak 73 orang $(54 \%)$, dan 62 orang $(45,9 \%)$ bekerja yang sebagian besar adalah karyawan swasta. Sedangkan menurut sumber pembiayaan sebagaian besar sumber biaya berobat dari Non BPJS sebanyak 107 orang (79,3\%). Dan pembiayaan tersebut sebagian besar dari asuransi swasta.

Menurut Jacobalis (2008), umur dan jenis kelamin merupakan salah satu faktor yang mempengaruhi persepsi konsumen terhadap mutu pelayanan kesehatan. Responden dalam penelitian ini didominasi pada kelompok usia $<40$ tahun $(74,8 \%)$ dan jenis kelamin perempuan $(78,5 \%)$. Hal ini dapat mempengaruhi perbedaan penilaian kepuasan. Kemudian tingkat pendidikan dapat mempengaruhi pola pikir rasional dan irrasional seseorang mengambil keputusan (self monitoring) menggunakan/memanfaatkan suatu pelayanan kesehatan (Snyder M, 2012). 
Responden yang didominasi latar belakang $(56,3 \%)$ berpendidikan Sarjana dan Diploma sehingga memiliki tuntutan yang lebih tinggi akan kepuasan pelayanan rawat inap. Sebagian besar ibu rumah tangga dengan pekerjaan suami rata-rata wiraswasta dan karyawan swasta, serta sebagian besar menggunakan sumber biaya dari asuransi lainnya.

Hasil penelitian ini tidak sama dengan hasil penelitian yang dilakukan Hendardjudani (2004), Suparman (2003), dan hasil penelitian Thoyib di IGD BRSUD Waled (2008). Hasil ini sesuai dengan tingkat pendidikan penduduk Kabupaten Cirebon, dimana yang mengecap pendidikan perguruan tinggi hanya $2 \%$. Notoatmojo (2005) mengemukakan bahwa semakin tinggi pendidikan, kemungkinan lebih mengerti dan memahami tentang penyakit, sehingga mereka lebih berfokus kepada tindakan preventif, akhirnya jarang yang sampai jatuh dalam kondisi sakit. Untuk jenis pekerjaan $86,7 \%$ responden berprofesi sebagai petani dan swasta, hal ini menunjukkan setiap rumah memiliki karakteristik yang berbeda.

\section{Gambaran Kepuasan Pasien terhadap Pelayanan Rawat Jalan di RS Azra}

\section{Dimensi Reliability}

Dimensi kehandalan (reliability) berkaitan dengan kemampuan perusahaan untuk memberikan layanan yang akurat sejak pertama kali tanpa membuat kesalahan apa pun dalam penyampaian jasanya sesuai dengan waktu yang disepakati. Rumah Sakit yang handal jika proses penerimaan paisen dilakukan dengan cepat dan prosedur pengadministrasian serta pembayaran yang praktis, tindakan yang cepat dan tepat terhadap pemeriksaan dan pengobatan, pemeriksaan laboratorium, kunjungan dokter, perawatan dijalankan dengan tepat serta penerimaan hasil pemeriksaan secara cepat dan tepat (Supranto, 2011). Dalam hal ini kebutuhan pasien adalah kebutuhan untuk sembuh dari sakit yang dapat dicapai melalui diagnosis yang tepat dan pengobatan yang tepat pula.

Dimensi reliability pelayanan rawat jalan RS Azra terhadap dalam penelitian ini ditunjukkan oleh empat atribut, yaitu kehandalan petugas pendaftaran, kehandalan pemeriksaan, kedisiplinan waktu, dan alur pelayanan.

Berdasarkan importance performance analysis melalui tingkat kesesuaian atribut pada Tabel 2 dari empat atribut yang mewakili dimensi reliability, semua atribut memuaskan pasien. Kuntjoro (2005) bahwa harapan utama saat pasien datang ke rumah sakit adalah kesembuhan dari penyakit yang diderita. Kesembuhan merupakan salah satu bukti keberhasilan kinerja pelayanan klinis, sehingga bila pasien sembuh bukan saja menunjukkan keberhasilan kinerja pelayanan, tetapi juga membuat pasien puas karena tujuan utamanya tercapai (Budayanti,2007). Dalam penelitian ini dalam dimensi reability, RS Azra telah sangat baik dalam memberikan pelayanan kepada pasien, sehingga semua atribut dengan hasil memuaskan dengan tingkat kesesuaian rata-rata 93,5\% atau di atas $90 \%$. Artinya pelayanan ini sudah dianggap handal, akurat dan terpercaya. Sebagaimana menurut Parasuraman et.al yang menyatakan reliability yaitu kemampuan perusahaan untuk memberikan pelayanan sesuai dengan apa yang dijanjikan secara akurat dan terpercaya.

\section{Dimensi Responsiveness}

Dimensi daya tanggap (responsiveness) berkaitan dengan kesediaan dan kemampuan karyawan untuk membantu pelanggan dan merespon permintaan mereka, serta menginformasikan kapan jasa akan diberikan. Rumah sakit dikatakan memiliki daya tanggap apabila petugas selalu siap sedia untuk membantu pasien pemberian informasi yang jelas kepada pasien, sistem pelayanan yang tidak berbelit-belit dan cepat tanggap terhadap keluhan pasien (Supranto,2002). 
Dimensi responsivness pelayanan rawat jalan pasien di RS Azra dalam penelitian ini ada empat atribut yaitu, ketanggapan dokter, kejelasan informasi petugas, kerja sama kerjasama antar petugas dan ketanggapan petugas. Seorang pelanggan akan mengharapkan bahwa ia seharusnya juga dilayani dengan baik apabila pelanggan yang lainnya dilayani dengan baik oleh penyedia jasa. Disinilah diperlukan responsivitas penyedia jasa untuk memperlakukan dan memanjakan pelanggan secara nyata pelanggan butuh dilayani dan dihargai tanpa membedakan status sosial ekonomi (Tjiptono F, 2000).

Berdasarkan importance performance analysis melalui tingkat kesesuaian atribut pada Tabel 2 diperoleh dari empat atribut keempat atribut dinyatakan sudah memuaskan pasien. Menurut Sugiarto dalam Nur Alam (2010), bahwa tingkat kepekaan yang tinggi terhadap pelayanan perlu diikuti dengan tindakan yang tepat sesuai dengan kebutuhan. Kepastian pelayanan merupakan bentuk layanan langsung dalam membantu pasien yang didukung oleh pengetahuan dan keterampilan.

Meskipun demikian, berdasarkan importance performance analysis diperoleh bahwa pelayanan rawat jalan berdasarkan dimensi responsivnes sudah dikatakan puas karena nilai tingkat kesesuaian dimensi ini diatas rata-rata. Artinya pelayanan sudah dinilai sigap dan cepat dalam pelayanan. Sedangkan Soraya (2011) menyebutkan responsiveness merupakan respon atau kesigapan karyawan dalam membantu pelanggan dan memberikan pelayanan yang cepat dan tanggap, yang meliputi kesigapan karyawan dalam melayani pelanggan, kecepatan karyawan dalam melayani transaksi, serta penanganan keluhan pelanggan.

\section{Dimensi Assurance}

Dimensi jaminan (assurance) berkenaan dengan perilaku karyawan yang mampu menumbuhkan kepercayaan pelanggan terhadap perusahaan dan menciptakan rasa aman bagi pelanggan. Rumah sakit dikatakan memiliki jaminan apabila pelayanan yang diberikan rumah sakit kepada pasien disertai dengan keahlian dokter dalam menetapkan diagnosis, ketrampilan dan pengetahuan personel medis, serta jaminan dan kepercayaan terhadap pelayanan yang diberikan (Supranto, 2011).

Dimensi assurance pelayanan pasien rawat jalan dalam penelitian ini ditunjukkan oleh lima atribut yaitu Kewajaran biaya/tarif dalam pelayanan, Pelayanan yang diberikan sesuai dengan standar pelayanan, Petugas kesehatan memberikan pelayanan sesuai dengan kebutuhan layanan kesehatan, RS memiliki sarana untuk menyampaikan pengaduan dan keluhan, Pengelohan keluhan dan pengaduan dilaksanakan dengan baik

Berdasarkan importance performance analysis melalui tingkat kesesuaian atribut pada Tabel 2 diketahui dari lima atribut yang mewakili dimensi assurance,. Semua atribut juga sudah dapat dikatakan memuaskan.

Salah satu elemen penting clinical governance adalah jaminan pasien atas pelayanan yang diberikan. Kekhawatiran pasien akan muncul jika dokter/perawat gagal memberikan jaminan atas pertolongannya. Hal ini terkait dengan kompetensi keahlian dan keilmuan. Pasien butuh kepastian, diagnosis dan prediksi kesembuhan yang tepat dan hal-hal yang berkaitan dengan keadaan penyakitnya (rasa aman) (Tjiptono F, 2000).

Berdasarkan importance performance analysis melalui tingkat kesesuaian atribut bahwa nilai ratarata kesesuaian dimensi assurance sudah dapat memuaskan pasien. Artinya dimensi ini sudah dinilai mampu memberikan jaminan atau keyakinan pasien dalam memperoleh informasi, sebagaimana menurut Kotler (2005) bahwa pengetahuan, kepercayaan dan kesopanan pemberi jasa 
untuk menimbulkan kepercayaan dan keyakinan yang berupa pengetahuan dan kemampuan petugas dalam bekerja, serta jaminan keamanan pelayanan dan kepercayaan terhadap pelayanan akan berdampak pada tingkat kepuasan pasien.

\section{Dimensi Emphaty}

Dimensi empati (emphaty) berkenaan dengan kemapuan perusahaan untuk memahami masalah pelanggan dan bertindak ramah demi pelanggan. Rumah sakit dikatakan memiliki dimensi empati apabila peduli terhadap keluhan pasien, kepedulian terhadap kebutuhan dan keinginan pasien, tidak pilih-pilih dalam memberikan pelayanan kepada semua pasien dan kesimpatikan dokter dan petugas terhadap pasien (Supranto, 2011).

Dimensi emphaty pelayanan rawat jalan di RS Azra pasien dalam penelitian ini ditunjukan oleh empat atribut, yaitu keramahan petugas, perhatian petugas rawat jalan, pelayanan yang tanpa memandang status sosial, serta komunikasi antara pasien dan petugas.

Berdasarkan importance performance analysis melalui tingkat kesesuaian atribut pada Tabel 2 diperoleh dari empat atribut yang mewakili dimensi emphaty, semua atribut yang dikatakan sudah dapat memuaskan pasien.

Disamping jaminan, salah satu elemen penting clinical governance lainnya adalah empati. Pasien membutuhkan perhatian dan komunikasi teraupetik yang harmonis. Perhatian yang diberikan penyedia pelayanan akan dapat memberikan rasa nyaman dan aman dalam menjalani perawatan (Tjiptono F, 2000).

Selain itu, berdasarkan nilai rata-rata tingkat kesesuaian dimensi emphaty dapat disimpulkan bahwa dimensi ini sudah dapat memuaskan pasien sebagaimana menurut Karl Albert dalam Yamit (2001) bahwa orang yang berinteraksi langsung dengan pelanggan harus memberikan pelayanan kepada pelanggan secara tulus, responsive, ramah, fokus, dan menyadari bahwa kepuasan pelanggan adalah segalanya.

\section{Dimensi Tangible}

Dimensi bukti fisik (tangible) berkaitan dengan daya tarik fasilitas fisik, kelengkapan, dan material yang digunakan perusahaan, serta penampilan karyawan. Rumah sakit memiliki bukti fisik yang baik apabila kondisi interior dan eksterior ruangan ditata secara menarik, kondisi kenyamanan dan kebersihan gedung, kerapihan dan kebersihan gedung, kerapihan dan kebersihan petugas, dan kecanggihan peralatan yang ada (Supranto,2011). Harapan pasien terhadap dimensi tangible merupakan keyakinan pasien sebelum menerima pelayanan yang nantinya akan dijadikan standar atau acuan dalam menilai pelayanan (Depkes RI, 2004).

Dimensi tangible pelayanan rawat jalan terhadap pasien di RS Azra dalam penelitian ini ditunjukkan oleh lima atribut, yaitu keramahan dan kesopanan oleh petugas, kebersihan dan rapihan ruangan rawat jalan, penataan ruangan, kelengkapan dan kersihan alat-alat yang dipakai, serta kerapihan petugas.

Berdasarkan importance performance analysis melalui tingkat kesesuaian atribut pada Tabel 2 diperoleh dari lima atribut yang mewakili dimensi tangible, semua atribut yang dikatakan sudah dapat memuaskan pasien.

Selain itu berdasarkan importance performance analysis diperoleh bahwa dimensi tangible memiliki nilai tingkat kesesuaian yang belum memuaskan pasien. Padahal dimensi ini menjadi 
penting sebagai ukuran dari pelayanan karena suatu bentuk jasa tidak bisa dilihat, dicium dan diraba. Sebagaimana menurut Soraya (2011) menyatakan karena suatu bentuk jasa. tidak bisa dilihat, dicium, diraba maka bukti fisik menjadi penting sebagai ukuran dari suatu pelayanan.

Kepuasan pasien terhadap dimensi tangible harus dipertahankan karena tangible yang baik menyebabkan harapan pasien terhadap pelayanan menjadi tinggi. Hal ini berkaitan dengan pernyataan Leonard L Berry, dimana jasa merupakan perbuatan, penampilan atau sebuah jasa yang dikonsumsi tetapi tidak dimiliki. Walaupun penampilan jasa diwakili oleh wujud tertentu, namun esensi yang dibeli adalah penampilan (Alma, 2007). Selain itu, menurut Perwani hal yang penting dalam housekeeping dan berkaitan erat dengan mutu produk/ jasa adalah bagaimana institusi penyedia pelayanan mampu menghadirkan keindahan, kerapihan, kebersihan, dan kelengkapan dan kesehatan terhadap produk jasa yang ditawarkan kepada pelanggan (Perwani, 2006).

\section{Strategi Peningkatan Kualitas Pelayanan Berdasarkan Analisis}

\section{Diagram Kartesius}

Perusahaan dapat mengetahui peringkat pelayanan menurut kepuasan pelanggan dan kinerja perusahaan serta mengidentifikasi tindakan apa yang perlu dilakukan manajemen perusahaan melalui penjabaran keseluruhan atribut kualitas pelayanan kedalam diagram kartesius (Supranto J, 2011).

Melalui importance performance analysis dapat pula diketahui letak dari pelaksanaan atribut setiap dimensi kualitas pelayanan yang mempengaruhi pasien. Sehingga dapat digunakan sebagai bahan pertimbangan untuk perbaikan kualitas. Berikut ini merupakan gambar diagram kartesius tingkat kepentingan (harapan) dan tingkat kinerja (kenyataan) dengan ke-empat kuadrannya.

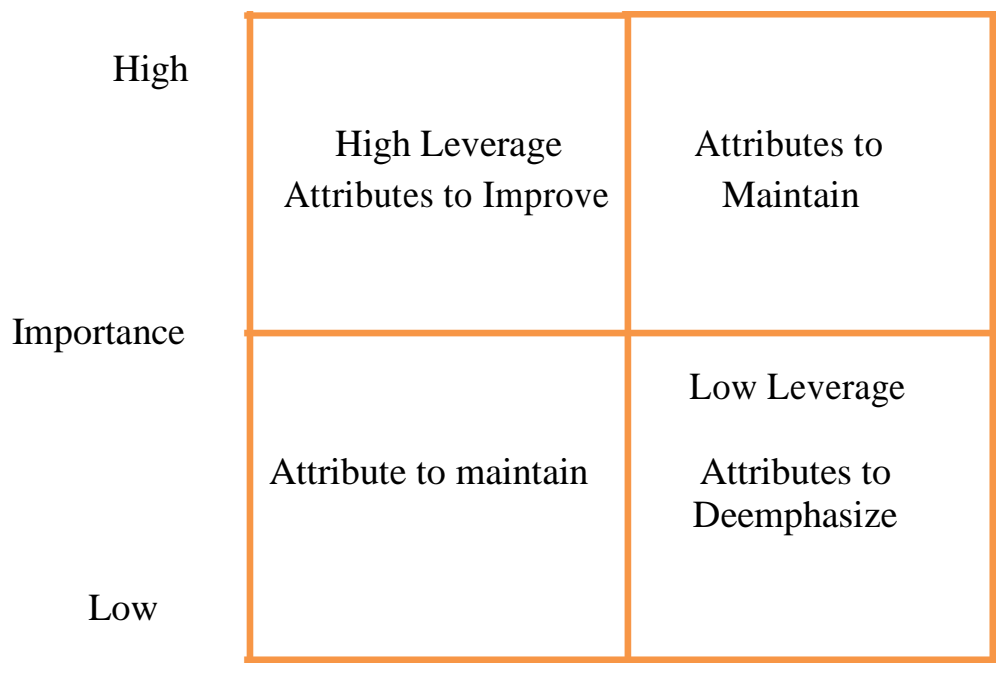

Gambar 2. Diagram Importance/Performance Matrix (Kartesius) Sumber: Measuring Customer Satisfactio

Berdasarkan gambar didapatkan posisi atribut dimensi kualitas pelayanan rawat jalan untuk pasien yang terbagi kedalam empat kuadran dengan menggunakan diagram kartesius yaitu: 


\section{Kuadran A (Attributes To Improve)}

Ini adalah wilayah yang memuat atribut-atribut yang dianggap penting oleh pasien rawat jalan, tetapi pada kenyataannya atribut-atribut ini belum sesuai seperti yang diharapkan (tingkat kepuasan yang dicapai masih rendah). Namun dalam penelitian ini tidak terdapat atribut yang memiliki perioritas rendah atau memerlukan perbaikan.

Menurut Pohan (2007), kuadran A adalah lokasi berbagai aspek atau atribut layanan kesehatan yang dirasakan penting oleh pasien, tetapi pelaksanaannya menurut pasien masih kurang. Dengan demikian, atribut layanan kesehatan harus menjadi perhatian utama di dalam peningkatan mutu atau kinerja.

Kuadran A merupakan posisi atribut yang memiliki high importance, low performance. Artinya kualitas atau kinerja pelayanan atribut tersebut sudah sesuai harapan pasien, sehingga berdampak pada kepuasan pasien.

\section{Kuadran B (Maintain Performance)}

Ini adalah wilayah yang memuat atribut-atribut yang dianggap penting oleh pasien dan atribut yang dianggap oleh pasien sudah sesuai dengan yang dirasakannya sehingga tingkat kepuasannya relatif tinggi. Atribut yang termasuk dalam kuadran ini adalah:

a. Item 1, Prosedur penerimaan pasien yang cepat dan tepat

b. Item 2, Pelayanan pemeriksaan diagnosis dan perawatan terhadap pasien yang cepat dan tepat

c. Item 4 , Prosedur pelayanan rawat jalan mudah

d. Item 15, Dokter Memberikan perhatian terhadap keluhan pasien dan keluarganya

e. Item 16, Petugas memberikan pelayanan kepada semua pasien tanpa memandang status sosial

f. Item 19, Kebersihan, kerapihan dan kenyamanan ruang rawat jalan

g. Item 21, Kelengkapan, kesiapan dan kebersihan alat-alat pemeriksaan yang digunakan

Kinerja atribut-atribut yang termasuk dalam kuadran ini harus dipertahan-kan karena semua atribut ini menjadikan pelayanan rawat jalan di RS Azra unggul di mata pasien. Sebagaimana menurut Pohan (2007) yang menyatakan semua aspek atau atribut yang terdapat pada kuadran B merupakan atribut yang dianggpa sangat penting oleh pasien, dan kinerja telah berada diatas penilaian rata-rata kinerja atau telah sejalan dengan harapan pasien atau hampir memuaskan. Sehingga atribut tersebut perlu dipertahankan.

\section{Kuadran C (Attributes to Maintain)}

Atribut yang berada dalam kuadran $\mathrm{C}$ merupakan atribut dengan prioritas rendah karena pengaruh atribut tersebut dianggap kurang begitu penting bagi pasien. Keadaan ini menunjukkan bahwa atribut yang berada dalam kuadran ini belum menjadi perhatian kebutuhan pasien.

Atribut yang berada dalam kuadran ini menunjukkan letak kelemahan pihak manajemen RS Azra dalam memenuhi kebutuhan pasien peserta rawat jalan, namun saat ini masih dianggap belum begitu penting. Berikut atribut-atribut yang masuk kedalam kuadran ini adalah:

a. Item 5, Kemampuan dokter dan perawat rawat jalan untuk cepat tanggap menyelesaikan keluhan pasien

b. Item 6, Petugas memberikan informasi dengan jelas, mudah dimengerti oleh pasien

c. Item 7, Dokter didampingi oleh perawat dalam memeriksa pasien

d. Item 11, Petugas kesehatan memberikan pelayanan sesuai dengan kebutuhan layanan kesehatan

e. Item 20, Penataan ruang rawat jalan (luar dan dalam)

f. Item 22, Kebersihan dan kerapihan penampilan petugas 
Menurut Pohan (2007) menyatakan semua aspek atau atribut yang terdapat dalam kuadran C merupakan atribut yang dianggap penting oleh pasien. Kinerja rumah sakit dalam kuadran ini telah memadai, meskipun belum dianggap penting bagi pasien. Namun dalam Kuadran C merupakan posisi atribut yang memiliki low importance dan low performance. Artinya kualitas atau kinerja pelayanan atribut tersebut masih dibawah rata-rata penilaian harapan. Meskipun tidak berdampak terhadap kepuasan pasien. Dengan demikian atribut ini mengindikasikan bahwa penilaian pelayanan masih di bawah harapan pasien, meskipun masih dalam level memuaskan

\section{Kuadran D (Low Leverage)}

Ini adalah wilayah yang memuat atribut-atribut yang dianggap kurang penting oleh pasien sedangkan pelakasanaanya sudah baik sehingga dirasakan terlalu berlebihan. Atribut-atribut yang termasuk dalam kuadran ini dapat dikurangi agar perusahaan dapat menghemat biaya maupun sumber daya.

a. Item 3, Jadwal pelayanan rumah sakit tepat waktu

b. Item 9 , Kewajaran biaya/tarif dalam pelayanan

c. Item 10, Pelayanan yang diberikan sesuai dengan standar pelayanan

d. Item 12, RS memiliki sarana untuk menyampaikan pengaduan dan keluhan

e. Item 13, Pengelohan keluhan dan pengaduan dilaksanakan dengan baik

Atribut yang terdapat pada kuadran D ini tidak butuh strategi peningkatan kualitas. Kuadran D merupakan posisi atribut yang memiliki low importance, high performance. Artinya kualitas atau kinerja pelayanan atribut tersebut sesuai dan melebihi harapan pasien, sehingga berdampak pada kepuasan pasien terhadap atribut tersebut. Atribut dalam kuadran ini harus dipertahankan guna menciptakan loyalitas dan minat pasien rawat jalan

\section{KESIMPULAN}

Berdasarkan penilaian Importance Perpormance Analysis dapat disimpulkan bahwa semua dimensi Reability, Responsivness, Assurance, Empaty dan Tangibel menunjukkan hasil memuaskan. Dengan demikian dapat disimpulkan bahwa pelayanan rawat jalan yang diberikan oleh Rumah Sakit Azra sudah baik dan perlu dipertahankan

Berdasarkan Hasil diagram kartesius terdapat 8 atribut yang teramsuk kedalam kuadran B sehingga perlu dipertahankan karena memiliki performance tinggi, 6 atribut dalam kuadran $\mathrm{C}$ masih harus ditingkatkan pelayanannya karena masuk ke level low importance dan low performance artinya kenyataan pelayanan yang diterima masih dibawah harapan pasien. Dan terdapat 5 atribut masuk kedalam kuadran D merupakan posisi atribut yang memiliki low importance, high performance. Artinya kualitas atau kinerja pelayanan atribut tersebut sesuai dan melebihi harapan pasien. 


\section{DAFTAR PUSTAKA}

Asmanningtyas, D. S. (2013). Metode Importance Analisys (IPA) Kepuasan Pasien Poliklinik Semarang tahun 2013. Kesehatan Masyarakat.

Azwar, A. A. (2009). Menjaga Mutu Pelayanan Kesehatan. Jakarta: Pustaka Sinar Harapan.

Chairunnisa dan Puspita Maya. (2015). Gambaran Kepuasan Pasien Rawat Jalan terhadap Pelayanan di Rumah Sakit Islam Jakarta Sukapura (RSIJS).

Kemenkes RI. (2010). Peraturan Menteri Kesehatan Republik Indonesia Nomor 147/Menkes/Per/I/2010 tentang Perizinan Rumah Sakit. Jakarta.

Laeliyah Nur dan Subekti Heru. (2017). Waktu Tunggu Pelayanan Rawat Jalan dengan Kepuasan. Jurnal Kedokteran dan Kesehatan Universitas Muhammadiyah Jakarta, https://doi.org/10.24853/jkk.13.1.9-27,

Ikbal Munawir. (2018). Faktor-faktor yang berhubungan dengan Kepuasan Pasien Rawat Jalan Rumah Sakit. Jurnal Ilmiah Kesehatan, Vol. 17 No.3.

Universitas Gadjah Mada. (2017, April 02). Diambil kembali dari Pasien Terhadap Pelayanan di Rawat Jalan RSUD Kabupaten Indramayu: http://journal.ugm.ac.id/jkesvo

Notoatmodjo, Soekidjo. (2010). Metodologi Penelitian Kesehatan. Jakarta:.Rineka Cipta.

Sabarguna, B. (2008). Pemasaran Pelayanan Rumah Sakit. Jakarta: Sagung Seto.

Solichah, Supartiningsih. (2017). Kualitas Pelayanan Kepuasan Pasien Rumah Sakit: Kasus Rawat Jalan di Rumah Sakit Sarila Husada Sragen. Jurnal Medicoeticolegal dan Manajemen Rumah Sakit, Vol 6 (1), 9-15.

Undang-Undang Republik Indonesia Nomor 44 tahun 2009 Tentang Rumah Sakit. 